\title{
Pentoxifylline and the proteasome inhibitor MG132 induce apoptosis in human leukemia U937 cells through a decrease in the expression of $\mathrm{BCl}-2$ and $\mathrm{BCl}-\mathrm{XL}$ and phosphorylation of p65
}

Alejandro Bravo-Cuellar ${ }^{1,2}$, Georgina Hernández-Flores', José Manuel Lerma-Díaz ${ }^{1,2}$, Jorge Ramiro Domínguez-Rodríguez ${ }^{1,3}$, Luis F Jave-Suárez ${ }^{1}$, Ruth De Célis-Carrillo ${ }^{1}$, Adriana Aguilar-Lemarroy ${ }^{1}$, Paulina Gómez-Lomeli ${ }^{1,4}$ and Pablo Cesar Ortiz-Lazareno ${ }^{1 *}$

\begin{abstract}
Background: In Oncology, the resistance of the cancerous cells to chemotherapy continues to be the principal limitation. The nuclear factor-kappa B (NF-KB) transcription factor plays an important role in tumor escape and resistance to chemotherapy and this factor regulates several pathways that promote tumor survival including some antiapoptotic proteins such as Bcl-2 and Bcl-XL. In this study, we investigated, in U937 human leukemia cells, the effects of PTX and the MG132 proteasome inhibitor, drugs that can disrupt the NF-KB pathway. For this, we evaluated viability, apoptosis, cell cycle, caspases-3, $-8,-9$, cytochrome $c$ release, mitochondrial membrane potential loss, p65 phosphorylation, and the modification in the expression of pro- and antiapoptotic genes, and the Bcl-2 and $\mathrm{BCl}-\mathrm{XL}$ antiapoptotic proteins.
\end{abstract}

Results: The two drugs affect the viability of the leukemia cells in a time-dependent manner. The greatest percentage of apoptosis was obtained with a combination of the drugs; likewise, PTX and MG132 induce G1 phase cell cycle arrest and cleavage of caspases $-3,-8,-9$ and cytochrome $c$ release and mitochondrial membrane potential loss in U937 human leukemia cells. In these cells, PTX and the MG132 proteasome inhibitor decrease p65 (NF-KB subunit) phosphorylation and the antiapoptotic proteins BCl-2 and BCl-XL. We also observed, with a combination of these drugs overexpression of a group of the proapoptotic genes $B A X, D I A B L O$, and FAS while the genes $B C L-X L$, MCL-1, survivin, IKB, and P65 were downregulated.

Conclusions: The two drugs used induce apoptosis per se, this cytotoxicity was greater with combination of both drugs. These observations are related with the caspases $-9,-3$ cleavage and G1 phase cell cycle arrest, and a decrease in p65 phosphorylation and BCl-2 and BCl-XL proteins. As well as this combination of drugs promotes the upregulation of the proapoptotic genes and downregulation of antiapoptotic genes. These observations strongly confirm antileukemic potential.

Keywords: U937, Apoptosis-related genes, Caspases, p65 phosphorylation, BCl-2, BCl-XL, pentoxifylline, MG132

\footnotetext{
* Correspondence: pablolazareno@gmail.com

'División de Inmunología, Centro de Investigación Biomédica de Occidente (CIBO), Instituto Mexicano del Seguro Social (IMSS), Sierra Mojada 800, Col.

Independencia, Guadalajara, Jalisco 44340, México

Full list of author information is available at the end of the article
} 


\section{Background}

Leukemia is a heterogenic group of diseases characterized by infiltration of neoplastic cells of the hematopoietic system into the blood, bone marrow, and other tissues $[1,2]$. Leukemia is the most common malignancy among people aged $<20$ years. In the last decade, these diseases have exhibited a clear ascending pattern in the morbidity index, becoming a great challenge to health institutions [3].

The main treatment for this disease is chemotherapy. However, its results are very often limited due to the treatment resistance that the neoplastic cells develop $[4,5]$. In an attempt to increase the efficiency of antileukemic treatments, higher doses of the cytotoxic agents have been used or different combinations of them [6,7], but in the majority of the cases, higher doses have been put into effect in an empirical manner without good results and incrementing side effects.

Given this situation, our research team has developed the concept of chemotherapy with a rational molecular basis. The former is based on the premise that chemotherapy acts mainly to induce a genetically programmed death of the cell called apoptosis, and that this depends in turn on the synthesis of proteins de novo and the activation of biochemical factors as a result of a modification in the balance between expression of pro- and antiapoptotic genes in response to treatment $[8,9]$. The cells undergoing apoptosis show internucleosomal fragmentation of the DNA, followed by nuclear and cellular morphologic alterations, which leads to a loss of the integrity of the membrane and the formation of apoptotic bodies. All of these processes are mediated by caspases, which are the main enzymes that act as apoptosis initiators and effectors. Some of these molecules can active themselves, while others require other caspases in order to acquire biological activity. This proteolytic cascade breaks down specific intracellular proteins including nuclear proteins of the cytoskeleton, endoplasmic reticulum, and cytosol, finally hydrolyzing the DNA [10-12].

On the other hand, it is noteworthy that upon apoptotic stimulus such as that generated by chemotherapy, this not only induces apoptosis but can also activate antiapoptotic mechanisms [13,14]. Similarly, the nuclear factor-kappa B (NF- $\kappa$ B) transcription factor plays an important role in tumor cell growth, proliferation, invasion, and survival. In inactive cells, this factor is linked with its specific inhibitor I-kappa B ( $\mathrm{K} B$ B), which sequesters NF- $\mathrm{kB}$ in the cytoplasm and prevents activation of target genes [15-18]. In this respect, NF-kB can activate antiapoptotic genes such as $B c l-2, B c l-X L$, and survivin, affecting chemotherapy efficiency, even if the chemotherapy itself or the radiotherapy itself can activate the NF-kB factor [19-21]. Blast cells exhibit overexpression of antiapoptotic proteins (Bcl-2 and $\mathrm{Bcl}-\mathrm{XL})$, which increase resistance to antitumor therapy [22].
In this regard, the drug PTX can prevent the phosphorylation of serines 32 and 36 of IкB, and we have found that PTX in combination with antitumor drugs such as adriamycin and cisplatin induced in vitro and in vivo a significant increment of apoptosis in fresh leukemic human cells [8], lymphoma murine models [9], and cervical cancer cells [23]. Similar results have also been observed with PTX in other studies [24]. PTX is a xanthine and a competitive nonselective phosphodiesterase inhibitor that inhibits tumor necrosis factor (TNF) and leukotriene synthesis and reduces inflammation [25,26]. The MG132 proteasome inhibitor is another drug that decreases NF$\mathrm{KB}$ activity [27]. Proteasome inhibitors are becoming possible therapeutic agents for a variety of human tumor types that are refractory to available chemotherapy and radiotherapy modalities $[28,29]$. The proteasome is a multicatalytic complex that is responsible for regulating apoptosis, cell cycle, cell proliferation, and other physiological processes by regulating the levels of important signaling proteins such as NF-кB, ІкB, and the MG132 proteasome inhibitor have been shown to induce apoptosis in tumor cells [30,31]. This is important because apoptosis is regulated by the ubiquitin/proteasome system at various levels [32]. The aim of the present work was to study in vitro in U937 leukemic cells the effects on viability, apoptosis, cell cycle, caspases cleavage, cytochrome $c$ release and mitochondrial membrane potential $(\Delta \Psi \mathrm{m})$, the $\mathrm{Bcl}-2$ and $\mathrm{Bcl}-\mathrm{XL}$ antiapoptotic proteins, and related genes activated by the PTX and/ or MG132 proteasome inhibitor, compounds that possess a NF-kB-mediated inhibitory effect.

\section{Methods}

Cells

The cell line U937 (ATCC CRL-1593.2), human monocytic leukemia, was used. These cells were cultivated in an RPMI-1640 culture medium (GIBCO, Invitrogen Co., Carlsbad, CA, USA) with the addition of $10 \%$ fetal bovine serum (FBS) (GIBCO), a 1\% solution of L-glutamine 100X (GIBCO), and antibiotics (GIBCO), which will be designated as RPMI-S. The cells were maintained at $37^{\circ} \mathrm{C}$ in a humid atmosphere containing $5 \% \mathrm{CO}_{2}$ and $95 \%$ air.

\section{Drugs}

PTX (Sigma-Aldrich, St. Louis, MO, USA) was dissolved in a sterile saline solution $(0.15 \mathrm{M})$ at a $200 \mathrm{mM}$ concentration and stored at $-4^{\circ} \mathrm{C}$ during a maximum period of 1 week. The MG132 proteasome inhibitor (N-CBZ-LEULEU-AL, Sigma-Aldrich) $0.5 \mathrm{mg}$ was dissolved in $0.250 \mathrm{~mL}$ of Dimethyl sulfoxide (DMSO, Sigma-Aldrich), divided into $20 \mu \mathrm{L}$ aliquots, and stored at $-20^{\circ} \mathrm{C}$. Immediately prior to use, this was diluted in RPMI-1640 culture medium at a final concentration of $1 \mu \mathrm{M}$. 


\section{Cell culture and experimental conditions}

U937 cells $\left(2.5 \times 10^{5}\right.$-mL in T75 flasks, Corning Incorporated, Corning, NY, USA) were grown in RPMI-S for 24 hours and collected by centrifugation. The cells were reseeded onto 24 well plates; U937 cells were either treated with PTX $(8 \mathrm{mM})$ or MG132 $(1 \mu \mathrm{M})$, or PTX + MG132 (final concentrations). The cells were incubated with PTX for 1 hour prior to the addition of MG132. All experiments were carried out 24 hours after treatment, to exception of the p65 phosphorylation that it was analyzed 1 hour after treatment with PTX or MG132 and in the gene expression studies the cells were incubated with the drugs for only 3 hours. The concentrations of the treatments employed in this study were previously confirmed as being the most favorable for the induction of apoptosis in this experimental model $[33,34]$.

\section{Cellular viability}

Cell viability was determined at different times in U937 cells $\left(2 \times 10^{4}\right)$. They were incubated with PTX, MG132 or PTX + MG132 during 18, 24, 36 and 48 hours, we use a WST-1 cell proliferation reagent commercial kit (BioVision, Inc. Milpitas, CA, USA) following the manufacturer's instructions. This study is based on the reduction of tetrazolium salts (WST-1) to formazan. After of the incubation $10 \mu \mathrm{L} /$ well of WST-1/ECS reagent was added and the U937 cell were incubated for another 3 hours. The absorbance was measured in a microplate reader (Synergy ${ }^{\text {TM }}$ HT Multi-Mode Microplate Reader; Biotek, Winooski, VT, USA) at $450 \mathrm{~nm}$ as reading reference wavelength at $690 \mathrm{~nm}$. Data are reported as the mean \pm standard deviation of the optical density values obtained in each group.

\section{Cell cycle analysis by flow cytometry}

For cell cycle analysis, the U937 cells were synchronized [35]. In brief, cells were culture in RPMI-1640 containing 5\% FBS by 12 hours then the cells were washed and culture in RPMI-1640 containing 1\% FBS overnight. After the cells were washed with PBS and changed to serum free medium for 18 hours, and finally the cells were passage and released into cell cycle by addition of $10 \%$ FBS in RPMI-1640 culture medium and $1 \times 10^{6}$ cells were treated 24 hours with the different drugs. The BD Cycletest ${ }^{\mathrm{TM}}$ Plus DNA Reagent Kit was used following the manufacturer's instructions (BD Biosciences, San Jose, CA, USA). DNA QC Particles (BD Biosciences) were used for verification of instrument performance and quality control of BD FACSAria I (BD Biosciences) cell sorter employed in DNA analysis. For each sample, at least 20,000 events were acquired and data were processed with Flowjo v7.6.5 software (Tree Star Inc., OR, USA).

\section{Assessment of apoptosis induction by PTX and MG132 proteasome inhibitor}

Apoptosis was evaluated by means of the Annexin V-FITC FLUOS Staining kit (Annexin-V-Fluos; Roche, Mannheim, Germany). Briefly, $1 \times 10^{6}$ U937 cells were treated 24 hours with PTX, MG132 or PTX + MG132 after that the samples were washed twice with PBS and resuspended in $100 \mu \mathrm{L}$ of incubation buffer; $2 \mu \mathrm{L}$ of Annexin V- Fluorescein Isothiocyanate (FITC) and $2 \mu \mathrm{L}$ of propidium iodide (PI) solution were added. The samples were mixed gently and incubated for $10 \mathrm{~min}$ at $20^{\circ} \mathrm{C}$ in the dark. Finally, $400 \mu \mathrm{L}$ of incubation buffer was added to each suspension, which was analyzed by flow cytometry. Annexin V- FITC-negative and PI-negative cells were considered live cells. Percentage of cells positive for Annexin V-FITC but negative for PI was considered to be in early apoptosis. Cells positive for both Annexin V-FITC and PI were considered to be undergoing late apoptosis and cells positive to PI were considered to be in necrosis. At least 20,000 events were acquired with the FACSAria I cell sorter and analysis was performed using FACSDiva software (BD Bioscience).

\section{Assessment of mitochondrial membrane potential by flow cytometry}

U937 cells $\left(1 \times 10^{6}\right)$ were treated 24 hours with the different drugs after that the cells were washed twice with PBS, resuspended in $500 \mu \mathrm{L}$ of PBS containing $20 \mathrm{nM}$ of 3,3dihexyloxacarbocyanine iodide ( $\mathrm{DIOC}_{6}$, Sigma-Aldrich), and incubated at $37^{\circ} \mathrm{C}$ for $15 \mathrm{~min}$ and the percentage of cells with $\Delta \Psi \mathrm{m}$ loss was analyzed by flow cytometry. As an internal control of the disrupted $\Delta \Psi \mathrm{m}$, cells were treated for 4 hours with $150 \mu \mathrm{M}$ of protonophore carbonyl cyanide m-chlorophenylhydrazone (CCCP, Sigma-Adrich) positive control. Flow cytometry was performed using FACSAria I (BD Biosciences). At least 20,000 events were analyzed with the FACSDiva Software (BD Biosciences) in each sample.

\section{Protein extraction for caspases-3, -8 and -9 and cytochrome $c$ and Western blot assay}

U937 cells $\left(5 \times 10^{6}\right)$ were treated with PTX, MG132 and PTX + MG132 for 24 hours. After treatment, cells were harvested, washed twice with PBS and lysed with RIPA buffer (0.5\% deoxycholate, 0.5\% NP-40, 0.5\% SDS, $50 \mathrm{mM}$ Tris $\mathrm{pH} 7.4$ and $100 \mathrm{mM} \mathrm{NaCl}$ ) containing protein inhibitors. Following sonication (15 pulses, 50\% amp), protein extracts were obtained after $30 \mathrm{~min}$ incubation at $4{ }^{\circ} \mathrm{C}$ and $5 \mathrm{~min}$ of centrifugation at $14,000 \mathrm{rpm} / 4^{\circ} \mathrm{C}$. Protein concentrations were determined using Dc Protein Kit (BioRad Laboratories, Inc., CA, USA). Total cell protein $(40 \mu \mathrm{g})$ was subjected to electrophoresis using a $10 \%$ sodium dodecyl sulfate (SDS) polyacrylamide gel. Subsequently, proteins were transferred to Immobilon-P PVDF 
membranes (Millipore, Bedford, MA, USA) and incubated with $1 \times$ Western blocking reagent (Roche) during 1.5 hour for nonspecific binding. Immunodetection of caspases-3, 8 and -9 were performed using anti-caspases $-3,-8$ and -9 antibodies (BioVision, Inc.) and cytochrome $c$ was effected using anti-cytochrome $c$ antibody (Biolegend, San Diego, CA, USA) at $4^{\circ} \mathrm{C}$ overnight. After incubation with a horseradish peroxidase-conjugated secondary antibody (Santa Cruz Biotechnology, CA, USA) immunoreactive proteins were visualized by Western blotting luminol reagent using the ChemiDoc ${ }^{\text {TM }}$ XRS equipment (Bio-Rad) with the Quantity One ${ }^{\circledR}$ 1-d Analysis Software (Bio-Rad). Control $\beta$-actin antibody (Santa Cruz Biotechnology). Protein levels on Western blot were quantified using the IMAGEJ 1.46r package (NIH, Bethesda, MD, USA).

\section{Detection of $\mathrm{Bcl}-2$ and $\mathrm{BCl}-\mathrm{XL}$ antiapoptotic proteins, and p65 phosphorylation by flow cytometry}

For determination of Bcl-2, Bcl-XL, and phosphorylated p65, $1 \times 10^{6}$ U937 cells were treated or not treated for 1 hour with PTX, MG132 or PTX + MG132. We employed Alexa Fluor ${ }^{\circledR}$ 647mouse anti-human Bcl-2 and Alexa Fluor $^{\circledR} 647$ mouse anti human Bcl-XL proteins (Santa Cruz Biotechnology) and Alexa Fluor ${ }^{\circledR} 647$ mouse antihuman NF-kB p65 (pS529) (BD Biosciences) antibodies. The staining procedures were according to protocol for detecting protein or activation of the phosphorylation state by flow cytometry. An appropriate isotype control was utilized in each test to adjust for background fluorescence, and the results are represented as the mean fluorescence intensity (MFI) of Bcl-2, Bcl-XL proteins, and phosphorylated p65 protein. For each sample, at least 20,000 events were acquired in a FACSAria I cell sorter (BD Biosciences) and data were processed with FACSDiva software (BD Biosciences).

\section{Quantitative real-time PCR}

Total RNA of the U937 cells $\left(5 \times 10^{6}\right)$ was obtained after 3 hours of incubation with the different treatments using the Purelink ${ }^{\mathrm{TM}}$ Micro-to-Midi purification system for total RNA (Invitrogen Co.). The DNAc was synthesized beginning with $5 \mu \mathrm{g}$ of total RNA utilizing the Superscript ${ }^{\mathrm{TM}}$ III First-Strand Synthesis Supermix kit (Invitrogen Co.). RealTime PCR was carried out with the System Light Cycler $^{\circledR}$ 2.0 (Roche Applied Science, Mannheim, Germany), for which we employed DNA Master plus SYBR Green I (Roche Applied Science). The PCR program consisted of an initial 10 -min step at $95^{\circ} \mathrm{C}$, and 40 cycles of 15 -sec at $95^{\circ} \mathrm{C}, 5$-sec at $60^{\circ} \mathrm{C}$, and 15 -sec cycles at $72^{\circ} \mathrm{C}$. Analysis of the PCR products was carried out with Light Cycler ${ }^{\circledR}$ software (Roche Applied Science). Data are presented in relative normalized quantities employing L32 ribosomal gene expression to verify the specificity of the amplified reaction, which was nearly $100 \%$. The oligonucleotides
(Invitrogen Co.) were designed in the data base of nucleotides of the Gen Bank of the National Information Center for Biotechnology (http://www.ncbi.nlm.nih.gov) using the oligo v.6 program (Table 1).

\section{Statistical analysis}

All experiments were carried out in triplicate and were repeated three times. The values represent mean \pm standard deviation of the values obtained. Statistical analysis was performed with the non-parametric MannWhitney $U$ test considering $p<0.05$ as significant. In some experiments, we calculated the $\Delta \%$, which represents the percentage of increase or diminution in relation to the corresponding untreated control group (UCG). For the different gene expressions, we considered significant variations as $\geq$ at $30 \%$ compared with the constitutive gene [8].

The committee of ethics, biosafety and research of CIBO approved the study with the number 1305-2005-16.

\section{Results}

PTX and MG132 proteasome inhibitor induce a decrease in viability in U937 cells

We evaluated the effect on viability of U937 leukemic cells treated with both drugs. PTX, MG132, or PTX + MG132 induce inhibition of cell viability in time-dependent manner (Figure 1). In the case of PTX or PTX + MG132 treated cells, these treatments at 18 hours exhibited similar behavior inducing around $60 \%$ of diminution of cell viability $(p<0.05 v s$ all groups). These values practically did not change in the other times. In contrast, at this same time the cellular viability was slightly modified by MG132 treatment ( $p<0.05 v s$ other treated groups) and reached similar values to those of the other two treated groups at 48 hours after treatment (optical density $=$ PTX $0.48 \pm 0.06$, MG132 $0.54 \pm 0.06$, PTX + MG132 $0.49 \pm 0.11, p<0.05$ vs untreated control group $1.87 \pm 0.9$ ).

\section{PTX and MG132 proteasome inhibitor induce G1 cell cycle arrest in U937 cells}

Our next interest was to elucidate whether the combination PTX + MG132 modulates the cell cycle. To address this point, U937 cells were treated in similar conditions with PTX, MG132 or PTX + MG132 for 24 hours and, subsequently, flow cytometry analysis of DNA content to determine cell populations in the different cell cycle phases was performed. As depicted in Figure 2, the percentage of untreated control group in G1 phase was $52.7 \pm 3.8 \%$. This percentage of cells is increased in PTX treated group $\Delta \%=25 \%$ and the maximum increment was observed in MG132 and PTX + MG132 treated groups with nearly to $\Delta \%=45 \%$ for both groups $p<0.05$. For the $\mathrm{S}$ phase opposite results were observed, and it was found $34.5 \pm 3.4 \%$ of U937 tumor cells in phase S; 
Table 1 Primer pair used for real-time (RT) quantitative PCR

\begin{tabular}{|c|c|c|}
\hline Gene & Primer pair sequences & Gen bank accession No. \\
\hline \multirow[t]{2}{*}{$\overline{B A K}$} & 5'CGC TTC GTG GTC GAC TTC AT 3' & NM001188 \\
\hline & $\overline{5^{\prime} A G A ~ A G G ~ C A A ~ A G A ~ C T T ~ C G C ~ T T A ~ 3 ' ~}$ & \\
\hline \multirow[t]{2}{*}{ BAX } & 5'TाT GCT TCA GGG TाT CAT CC 3' & NM138764 \\
\hline & $\overline{5^{\prime} \text { CAG TTG AAG TTG CCG TCA GA } 3^{\prime}}$ & \\
\hline \multirow[t]{2}{*}{$D I A B L O$} & 5'TGA CTT CAA AAC ACC AAG AGT A3' & NM019887 \\
\hline & 5'TTा CTG ACG GAG CTC TTC TA 3' & \\
\hline \multirow[t]{2}{*}{$\overline{D R 4}$} & 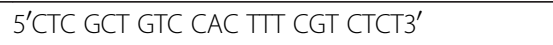 & NM003844 \\
\hline & 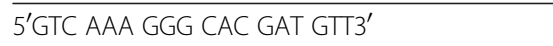 & \\
\hline \multirow[t]{2}{*}{$\overline{F A S}$} & 5'TGA ACA TGG AAT CAT CAA GGA3' & NM000043 \\
\hline & 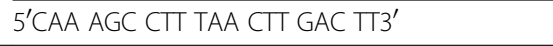 & \\
\hline \multirow[t]{2}{*}{$\overline{B C L-X L}$} & 5'GCA GGC GAC GAG TाT GAA CT 3' & NM138578 \\
\hline & $\overline{5^{\prime} \text { GTG TCT GGT CAT TTC CGA CTG A } 3^{\prime}}$ & \\
\hline \multirow[t]{2}{*}{ MCL-1 } & $5^{\prime}$ CAC GAG ACG GTC TTC CAA GGA TGC T 3' & NM021960 \\
\hline & 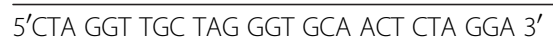 & \\
\hline \multirow[t]{2}{*}{ SURVIVIN } & 5'TGA GCT GCA GGT TCC TTA TCT G 3' & NM001168 \\
\hline & 5'GAA TGG CTT TGT GCT TAG TIT T 3' & \\
\hline \multirow[t]{2}{*}{$I k B a$} & 5'GGA TAC CTG GAG GAT CAG ATT A 3' & NM001278 \\
\hline & $\overline{5^{\prime} C C A}$ CCT TAG GGA GTA GTA GAT CAA T 3' & \\
\hline \multirow[t]{2}{*}{$P 65$} & $5^{\prime}$ GCA GGC TCC TGT GCG TGT CT $3^{\prime}$ & NM02975 \\
\hline & 5'GGT GCT CAG GGA TGA CGT AAA G $3^{\prime}$ & \\
\hline \multirow[t]{2}{*}{ RPL32 } & $5^{\prime}$ GCA TTG ACA ACA GGG TTC GTA G $3^{\prime}$ & NM000994 \\
\hline & 5'ATT TAA ACA GAA AAC GTG CAC A $3^{\prime}$ & \\
\hline
\end{tabular}

Oligonucleotides were designed using the Oligo v.6 software. Gene sequences were obtained from the GenBank Nucleotide Database of the National Center for Biotechnology Information (NCBI) (http://www.ncbi.nlm.nih.gov).

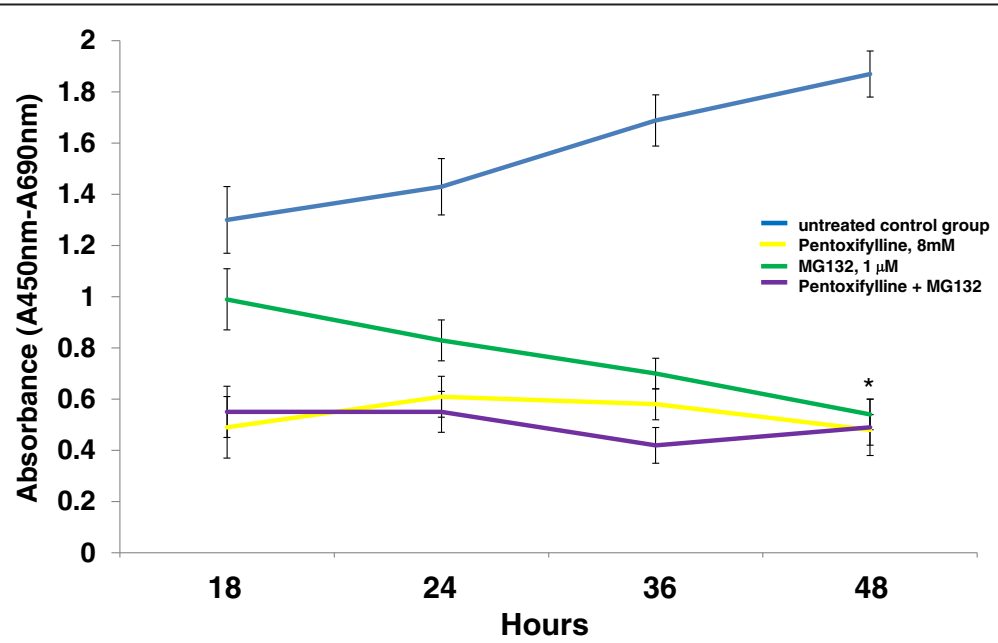

Figure 1 Evaluation of viability in U937 human leukemia cells treated with PTX, MG132 and PTX + MG132. U937 cells were incubated in the presence of PTX, MG132, or PTX + MG132 for 18, 24, 36, and 48 hours as previously indicated. After incubation, WST-1 was added and 3 hours later, viability was assessed by spectrophotometry at $450 \mathrm{~nm}$. The results represent mean \pm standard deviation of three independent experiments performed in triplicate. Statistical analysis Mann-Whitney $U$ test. $p<0.05$ PTX or PTX + MG132 vs untreated control group or MG132 group. $\bullet p$ $<0.05$ PTX + MG132 vs all groups. * $p<0.05$ PTX, MG132 or PTX + MG132 vs untreated control group. 


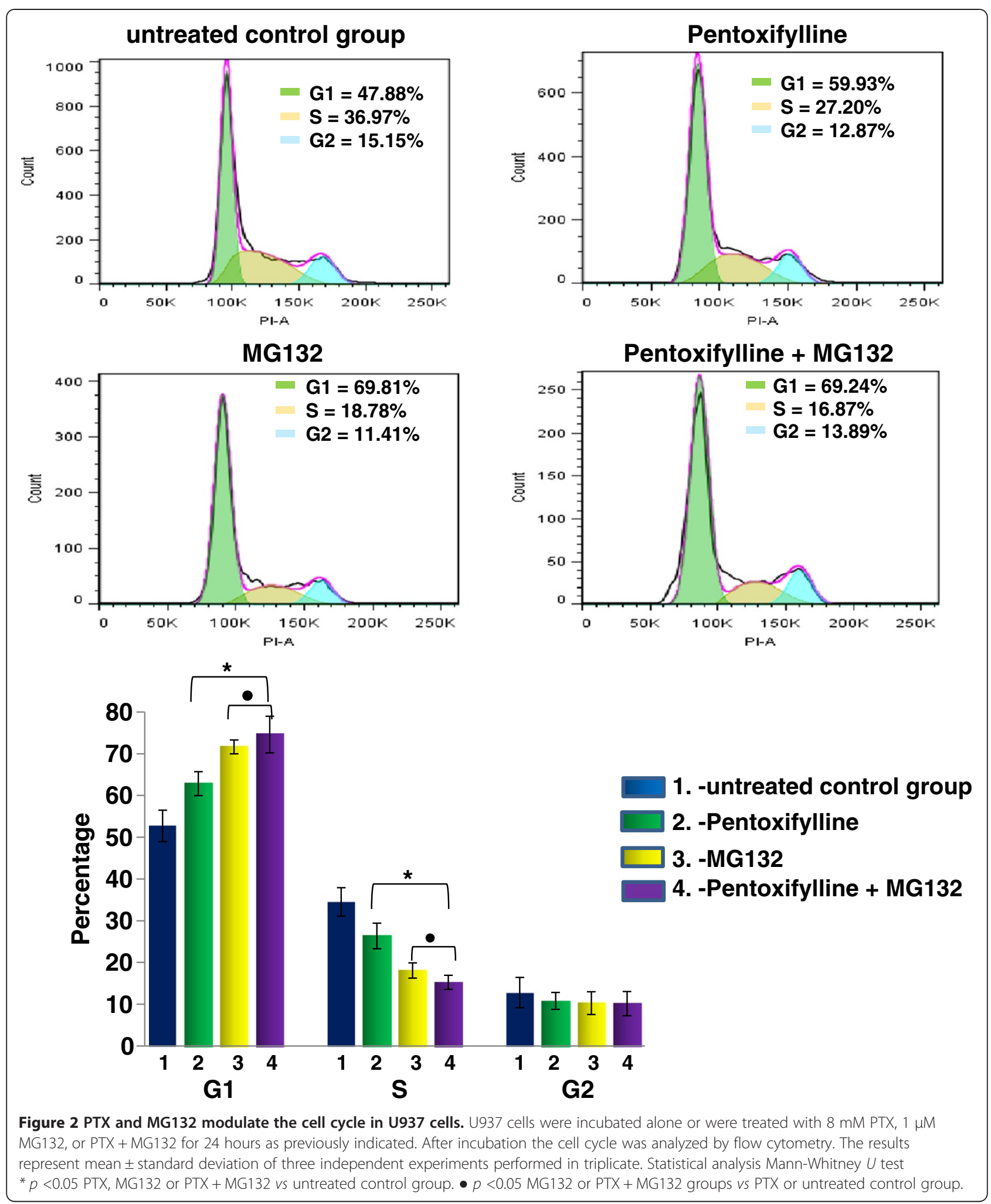


however, the $\Delta \%$ in PTX, MG132 or the combination of both drugs were $-26.4 \%,-49.2 \%$ and $-54.3 \%$ respectively $p<0.05$. Finally for the $\mathrm{G} 2$ phase the percentage of cells from untreated control group was $12.8 \pm 3.6 \%$, it diminished in treated groups $\Delta \%=-15.2 \%,-24.5 \%,-10.9 \%$ for PTX, MG132 and PTX + MG132 groups respectively. These observations suggest that PTX and MG132 or its combination induce a cell arrest in the G1 phase.

\section{Apoptosis induction by PTX + MG132}

At 24 hours of culture, apoptosis was evaluated in the U937 human leukemia cells that was induced by the different treatments under experimental conditions as previously described. In Figure 3 , it is observed that the untreated control group showed a low percentage of early and late apoptosis $(2.1 \pm 0.9 \%$ and $2.6 \pm 1.1 \%$ respectively) compared with the group treated exclusively with either PTX $(18.2 \pm 2.1 \%$ and $28.5 \pm 7.3 \%$ of early and late apoptosis, respectively, $p<0.05$ ), or treated with MG132 proteasome inhibitor so we observed $28.1 \pm 8.1 \%$ and $20.7 \pm 6.6 \%$ of early and late apoptosis, respectively ( $p<0.05 v s$ untreated control group). It was also very interesting to observe that the group of cultures exposed to PTX + MG132 showed a greater percentage of late apoptosis $44.1 \pm 4.5 \%$ in comparison with all other groups $p<0.05$.

\section{PTX + MG132 induce mitochondrial membrane potential $(\Delta \Psi \mathrm{m})$ loss}

As mitochondria plays an important role in apoptosis, for that reason we determined the $\Delta \Psi \mathrm{m}$ in U937 leukemia cells treated with PTX, MG132 or PTX + MG132 and the results are represented in the Figure 4 . The $\Delta \Psi \mathrm{m}$ did not change in untreated control group. However when the cells were treated with either PTX or MG132 an important loss of the $\Delta \Psi \mathrm{m}$ were noted $43.4 \pm 4.7 \%$ and $46.8 \pm 6.6$ respectively $(p<0.05$ compared with untreated control group), and it is interesting that PTX + MG132 induce an important $\Delta \Psi \mathrm{m}$ loss in U937 cells $62.7 \pm 3.7 \%$, in comparison with the other groups $p<0.05$.

PTX + MG132 increase cleavage in caspases-3, -9 and cytochrome $c$ release

We determined caspases $-3,-8,-9$ and cytochrome $c$ by Western blot. The analysis reveals that the combination PTX + MG132 was more effective in the activation of

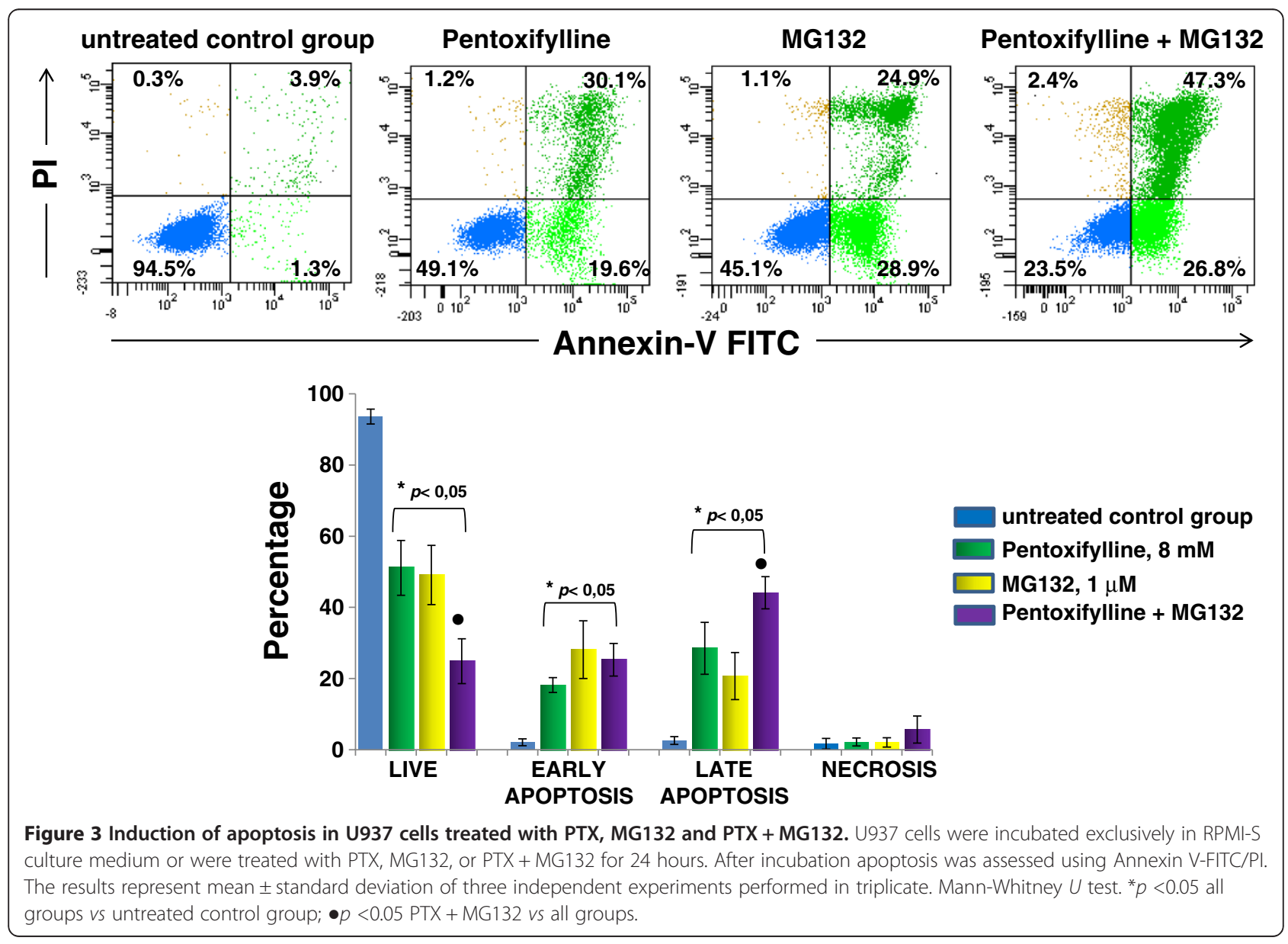




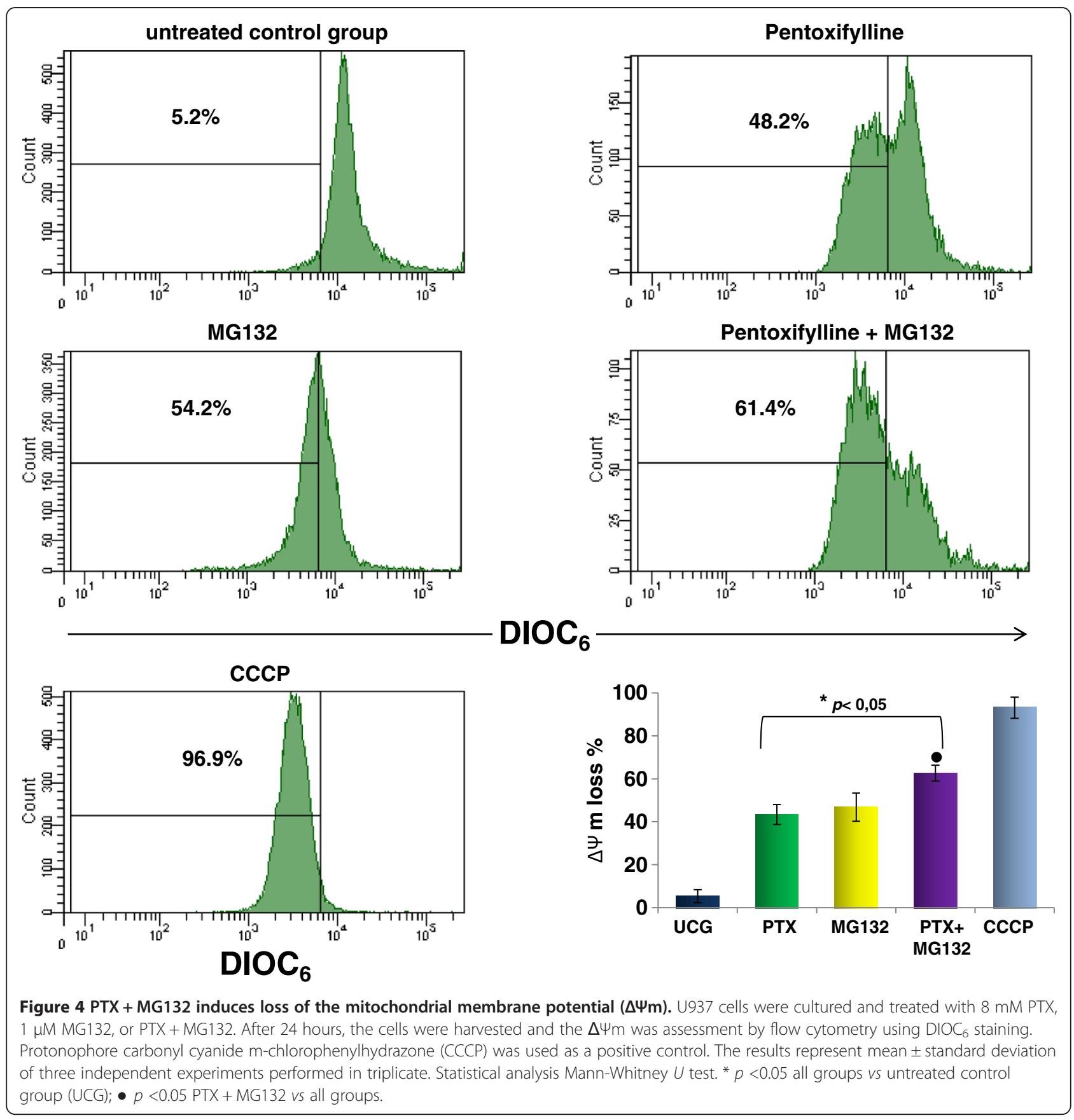

caspases-9 and -3 . The results in Figure 5 allow us to observe that PTX increase cleavage of caspases- 9 (2.8 fold) and -3 (10.4 fold), and the release of cytochrome $c(5.2$ fold) compared with untreated control group $p<0.05$. In similar way MG132 proteasome inhibitor increase cleavage of caspase- 3 in 5.4 fold, caspase- 9 in 1.7 fold and caspase- 8 in 1.4 fold change and release of cytochrome $c$ in 4.8 fold compared with untreated control group $p<0.05$. It is important to stress that when we used PTX + MG132 we observed considerably cleavage of caspase-9 (13.5 fold) and caspase-3 (13.4 fold) compared with PTX or MG132 alone and with untreated control group, $p<0.05$. In the same way, when we use both drugs simultaneity we observed an increase in the release of cytochrome $c$ (5.11 fold) and cleavage of caspase- 8 (1.88 fold) in comparison with untreated control group $p<0.05$.

\section{Determination by flow cytometry of phosphorylated p65} protein from NF-KB, Bcl-2 and $\mathrm{Bcl}-\mathrm{XL}$ antiapoptotic proteins The phosphorylated p65 protein was quantified determining the Mean Fluorescence Intensity by flow cytometry. As we expected, in comparison with the Untreated 


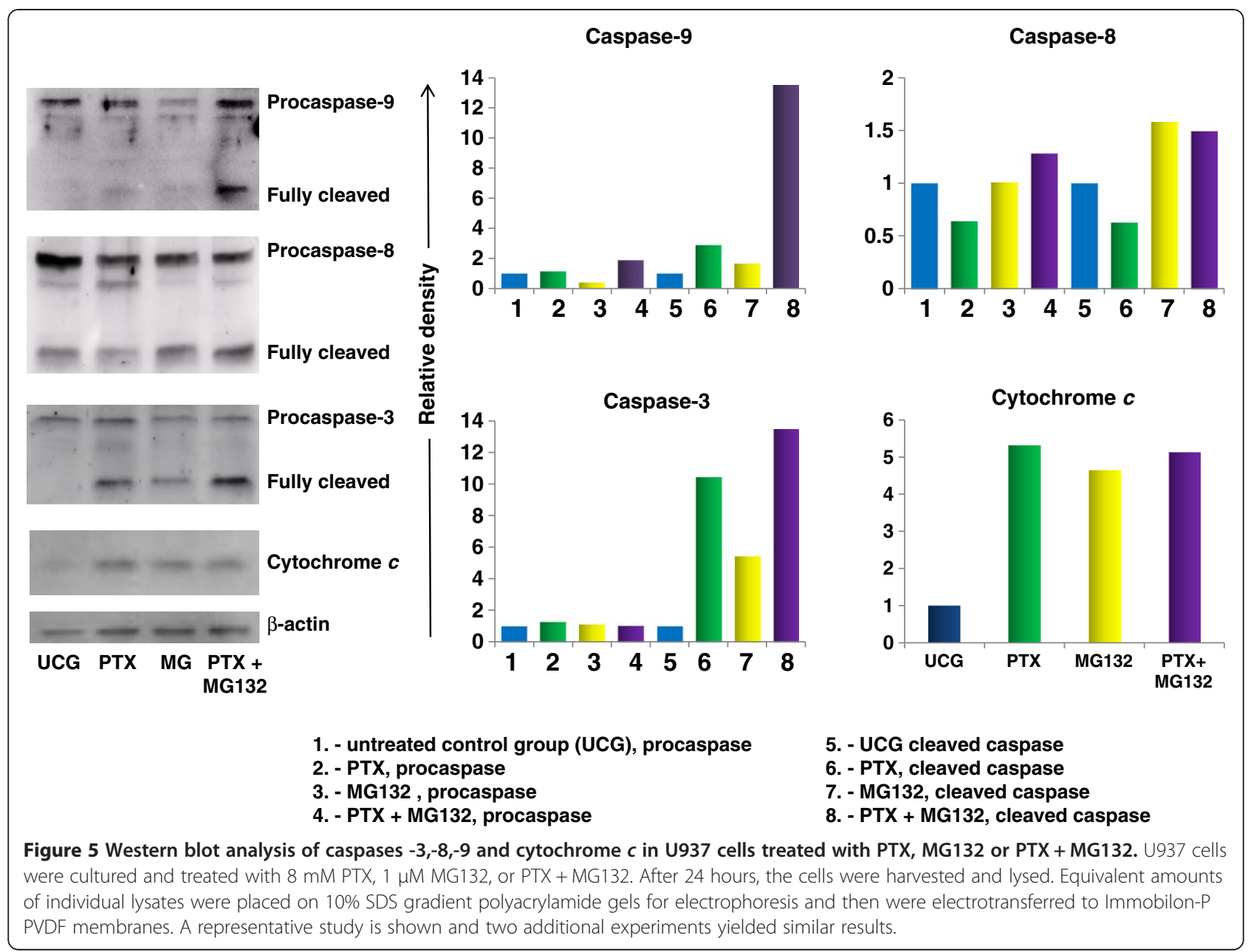

Control Group, Figure 6 shows that U937 human leukemia cells treated with PTX or the MG132 proteasome inhibitor decrease the phosphorylation of p65 $(p<0.05)$, and in the combination of both compounds, this diminution is more pronounced. The antiapoptotic proteins $\mathrm{Bcl}-2$ and Bcl-XL play a transcendent role in chemoresistance in tumor cells; therefore, these proteins could be regulated by the NF- $\mathrm{KB}$ transcription factor. For this, we studied the effect of PTX and MG132 in these proteins. We can observe in Figure 7A that tumor U937 cells treated with PTX, MG132, or PTX + MG132 in a similar manner reduce the expression of $\mathrm{Bcl}-2$ protein in comparison with the untreated control group $(p<0.05)$. In the same way, in Figure 7B, we can see that when U937 cells were treated with the same schedule of treatments. We also observed a reduction in $\mathrm{Bcl}-\mathrm{XL}$ in comparison with the untreated control group $(p<0.05)$, with a tendency to be the most pronounced in the group treated with both drugs. These results together are according with apoptosis, caspases cleavage, and cytochrome $c$ release and $\Delta \Psi \mathrm{m}$ loss experiments and strongly suggest that assayed treatments inhibited the expression of important proteins related with

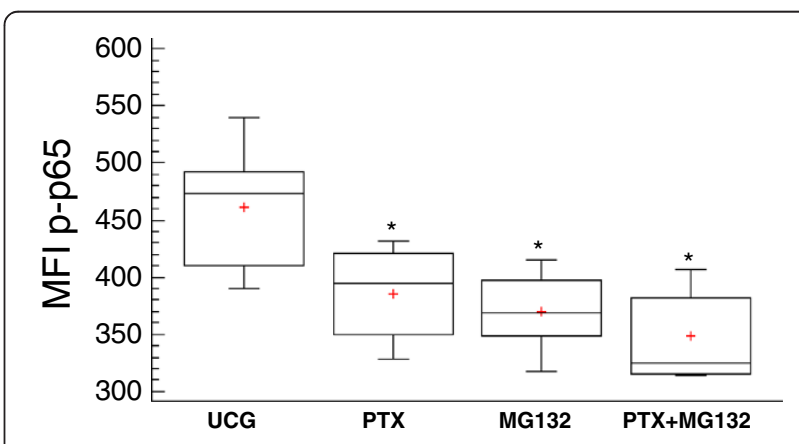

Figure 6 Determination of phosphorylated p65 (NF-KB subunit) in U937 cells treated with PTX, MG132 and PTX + MG132. U937 cells were incubated either alone or treated with $8 \mathrm{mM} \mathrm{PTX}, 1 \mu \mathrm{M}$ MG132, or PTX + MG132. After 1 hour, the phosphorylated p65 protein was determined by flow cytometry. For each sample at, least 20,000 events were acquired. The results represent mean \pm standard deviation of the Mean Fluorescence Intensity (MFI) of phosphorylated p65 of three independent experiments carried out in triplicate. ${ }^{*} p<0.01$ vs the untreated control group. 


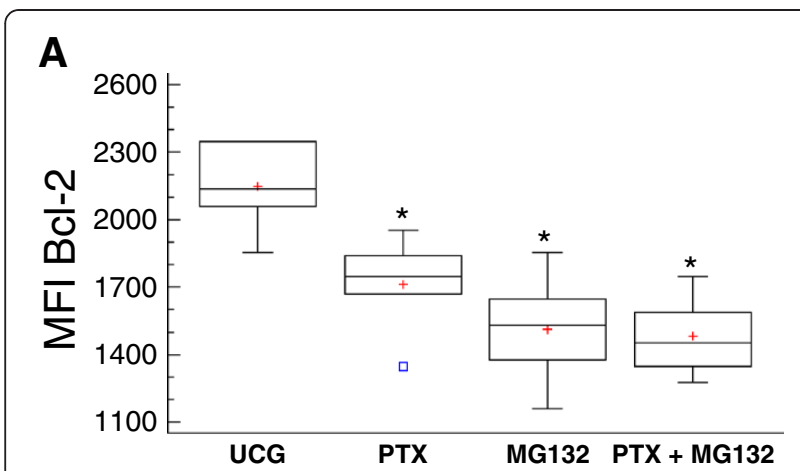

B

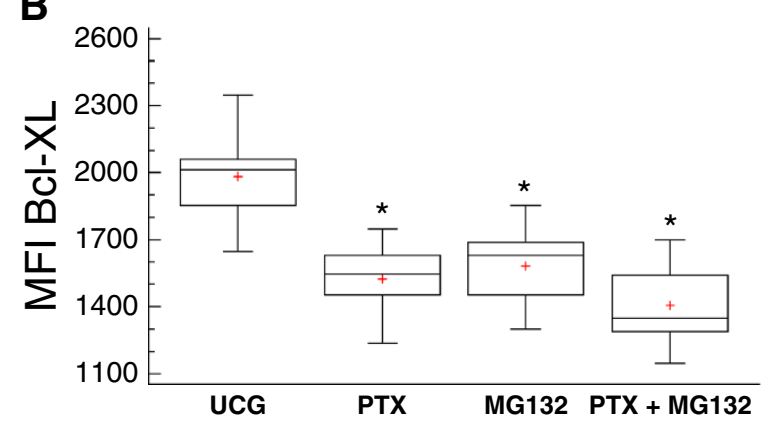

Figure 7 PTX and MG132 reduce the expression of $\mathrm{Bcl}-2$ and Bcl-XL antiapoptotic proteins in U937 cells. U937 human leukemia cells were incubated alone or were treated with $8 \mathrm{mM}$ PTX, 1 MM MG132, or PTX + MG132. After 24 hours the BCl-2 (A) and $\mathrm{BCl}-\mathrm{XL}(\mathbf{B})$ antiapoptotic proteins were determined by flow cytometry. For each sample, at least 20,000 events were acquired. The results represent mean \pm standard deviation of the Mean Fluorescence Intensity (MFI) of $\mathrm{BCl}-2$ or of $\mathrm{BCl}-\mathrm{XL}$ of three independent experiments carried out in triplicate. ${ }^{*} p<0.01$ vs the untreated control group.

the survival of the cells, being most important with the combination of the drugs.

\section{Changes in the expression of proapoptotic, antiapoptotic, and NF-KB-related genes}

Real-Time PCR was employed to determine relative change in gene expression (Figure 8). Arbitrary was considered as significant upregulation or downregulation when the change was $\geq 30 \%$ in relation to constitutive gene. In PTX-treated U937 cells, we found upregulation of $B A X, D I A B L O, D R 4$, and FAS proapoptotic genes in comparison with untreated control group, and the most important upregulation observed with $B A X$ (2.17-fold upregulation). Similarly, PTX induces downregulation of $B C L-X L$ and $M C L-1$ antiapoptotic genes and of $I \kappa B$ and $p 65 \mathrm{NF}-\kappa B$-related genes. When U937 culture cells were treated with the MG132 proteasome inhibitor, we observed upregulation of $B A X, D I A B L O$, and $F A S$ genes. In the case of antiapoptotic genes, MG132 induces downregulation of Survivin and $p 65$ genes. When the cell cultures were treated with PTX + MG132 we observed upregulation of the proapoptotic genes $B A X$ with the greatest upregulation (4.6-fold upregulation), and with $F A S$ and DIABLO genes. In relation to PTX + MG132-treated U937 culture cells antiapoptotic genes $B C L-X L, M C L-1$, and Survivin were downregulated as well as the NF-kB-related genes $I_{\kappa} B$ and $p 65$. In general, with these treatment schedules the data suggest a balance in favor of proapoptotic genes in U937 human leukemia cells treated with PTX + MG132.

\section{Discussion}

In the present work, we studied the viability of U937 human leukemia cells treated with PTX and/or MG132 using the spectrophotometric assay of WST-1 as well as apoptosis by flow cytometry. These results are in agreement between them and with prior experiments clearly showing that PTX and MG132 possess an important antitumor activity per se, as has been reported [24,36]. This increasing in cytotoxicity when the drugs are added simultaneously to tumor cell cultures in an important manner, suggests an additive effect. In addition, the fact of having found a clear effect of time-dose dependence speaks to the specificity of the treatments. In this respect, the potential of PTX and MG132 is great because there reports of successful combinations of PTX with antitumoral drugs such as adriamycin [8] and cisplatin [23], and MG132 can synergize the antitumoral activity of TRAIL receptor agonist [37] and propyl gallate [38]. In these sense our study conincide with these reports because we observe an important induction of late apoptosis (44.1\%) when we use the combination PTX + MG132 in U937 leukemia cells.

The growth arrest of tumor cells in G1 phase provides an opportunity for cells to either undergo apoptosis or induce cell repair mechanisms [39,40]. Interestingly, in our study we observed with the different treatment arrest in G1 phase and apoptosis induction. In this point apparently the lower percentages of cells in $S$ phase are due to MG132 effect because the percentage of cells treated exclusively with the proteasome inhibitor shows the same values than the cells treated with PTX + MG132, suggesting different action mechanisms between two drugs.

Based in the correlation of our observations related with the $\Delta \Psi \mathrm{m}$ loss, cytochrome $c$ release, caspase assays we think that apoptosis observed it is due principally to the mitochondrial pathway. In addtion these results together are in aggremeent with previously reports [41,42].

It is known that PTX prevents the activation of NF- $\mathrm{KB}$ by avoiding the breakdown of its inhibitory molecule, ІкB [43]; MG132 is also an NF-kB inhibitor as well as of the proteasome [44]. We used both drugs in our experiments in order to observe the modifications in p65 (NF-kB subunit) phosphorylation. In U937 leukemic cells, we found a 
decrease in p65 phosphorylation with PTX and MG132 or its combination compared with untreated cells $(p<0.05)$. The fact that the experimental treatment induces a decrease in NF- $\mathrm{kB}$ phosphorylation allows us to suppose the presence of important alterations in a mechanism that promotes resistance to antitumor therapy $[45,46]$.

We decided to study the Bcl-2 and Bcl-XL proteins that possess antiapoptotic activity that can be regulated by NF-kB activation $[47,48]$. In others tumor cells have shown an overexpression of these proteins promoting a resistance to radiotherapy or chemotherapy [49,50]. Likewise, some studies have reported that various chemotherapeutic agents commonly used upregulated Bcl-2 and Bcl-XL expression through the NF-kB-dependent pathway [51,52]. These proteins suppress apoptosis by preventing the activation of the caspases that carry out the process $[53,54]$. The susceptibility in U937 leukemia cells to apoptosis induced by PTX and MG132, it can explain for the decrease in the expression of $\mathrm{Bcl}-2$ and $\mathrm{Bcl}-\mathrm{XL}$ proteins when the cells are expose to both drugs. Moreover the decrease in the levels of Bcl-2 leads to $\Delta \Psi \mathrm{m}$ loss potential. This fact is key event for the apoptosis induction [55]. The data suggest that PTX + MG132 treatment induces caspasesdependent mitochondrial intrinsic pathway because we found disruption in mitochondrial membrane potential, cytochrome $c$ release and an important cleavage of caspases-9 and it is well known that it leads to caspase -3 cleavage and apoptosis induction [56]. Our result show that the proapoptotic genes exhibited upregulation with the different treatments and this tendency is observed mainly in $B A X, D I A B L O$, and FAS genes. Contrarily, the antiapoptotic genes were downregulated, mainly $B C L-X L$, $M C L-1$, and survivin.

It is important to stress that in relation to proapoptotic genes study we found the highest upregulation in the $B A X$ gene and this is in agreement with our data in relationship to the mitochondrial pathway participation observed in this paper.

Above suggests that there is a gene balance that favors apoptosis induction. We found a downregulation in the $I \kappa B$ when leukemia cells were treated with PTX or PTX + MG132 and in $p 65$ genes when U937 leukemic cells were treated with PTX, MG132, or its combination, suggesting a diminution of the biological availability of these factors that facilitate cell death.

\section{Conclusion}

Our results show that in this experimental model with U937 human leukemia cells, PTX and MG132 showed antileukemic activity, and together have an additive effect. These drugs disturb the NF- $\mathrm{B}$ p pathway and induce cell arrest in G1 phase, and decrease of antiapoptotic proteins $\mathrm{Bcl}-2$ and $\mathrm{Bcl}-\mathrm{XL}$ and induce $\Delta \Psi \mathrm{m}$ loss, cytochrome c release and a caspases-3,-9,-8 cleavage resulting in an increase in apoptosis. In addition the different treatments gave rise to equilibrium in favor of the expression of proapoptotic 
genes. For these previously mentioned reasons, in general our results support the idea that chemotherapy must be administered under rational molecular bases.

\section{Competing interests}

The author declares no potential conflict of interests.

\section{Authors' contributions}

PCO- $\mathrm{L}, \mathrm{AB}-\mathrm{C}$, and $\mathrm{GH}-\mathrm{F}$ designed and performed the research, analyzed the data, and drafted the manuscript; JML-D, JRD-R, PG-L, and RC-C performed some of the research and analyzed the data, and AA-L and LFJ-S conducted the molecular study and analyzed the data. All of the authors read and approved the final manuscript.

\section{Acknowledgments}

This work was supported by a grant (FIS/IMSS/PROT/283) from the Instituto Mexicano del Seguro Social (IMSS). We thank to our technicians Marlin Corona Padilla and María de Jesús Delgado Ávila.

\section{Author details}

'División de Inmunología, Centro de Investigación Biomédica de Occidente (CIBO), Instituto Mexicano del Seguro Social (IMSS), Sierra Mojada 800, Col. Independencia, Guadalajara, Jalisco 44340, México. ²Departamento Ciencias de la Salud, Centro Universitario de los Altos, Universidad de Guadalajara, Tepatitlán de Morelos, Jalisco, México. ${ }^{3}$ Departamento de Farmacobiología, Centro Universitario de Ciencias Exactas e Ingeniería, Universidad de Guadalajara, Guadalajara, Jalisco, México. ${ }^{4}$ Programa de Doctorado en Ciencias Biomédicas Orientación Inmunología, Centro Universitario de Ciencias de la Salud, Universidad de Guadalajara, Guadalajara, Jalisco 44340, México.

Received: 4 July 2012 Accepted: 18 February 2013

Published: 28 February 2013

\section{References}

1. Wu CP, Qing X, Wu CY, Zhu H, Zhou HY: Immunophenotype and increased presence of CD4(+)CD25(+) regulatory T cells in patients with acute lymphoblastic leukemia. Oncol Lett 2012, 3(2):421-424.

2. Simon T, Anegon I, Blancou P: Heme oxygenase and carbon monoxide as an immunotherapeutic approach in transplantation and cancer. Immunotherapy 2011, 3(4 Suppl):15-18.

3. Terracini B: Epidemiology of childhood cancer. Environ Health 2011 10(Suppl 1):S8

4. Snead JL, O'Hare T, Eide CA, Deininger MW: New strategies for the firstline treatment of chronic myeloid leukemia: can resistance be avoided? Clin Lymphoma Myeloma 2008, 8(Suppl 3):S107-S117.

5. Shaffer BC, Gillet JP, Patel C, Baer MR, Bates SE, Gottesman MM: Drug resistance: still a daunting challenge to the successful treatment of AML. Drug Resist Updat 2012, 15(1-2):62-69.

6. Martelli AM, Chiarini F, Evangelisti C, Ognibene A, Bressanin D, Billi AM Manzoli L, Cappellini A, McCubrey JA: Targeting the liver kinase B1/AMPactivated protein kinase pathway as a therapeutic strategy for hematological malignancies. Expert Opin Ther Targets 2012, 16(7):729-742.

7. Benelli R, Vene R, Ciarlo M, Carlone S, Barbieri O, Ferrari N: The AKT/NFkappaB inhibitor xanthohumol is a potent anti-lymphocytic leukemia drug overcoming chemoresistance and cell infiltration. Biochem Pharmacol 2012, 83(12):1634-1642.

8. Bravo-Cuellar A, Ortiz-Lazareno PC, Lerma-Diaz JM, Dominguez-Rodriguez JR, Jave-Suarez LF, Aguilar-Lemarroy A, del Toro-Arreola S, de Celis-Carrillo R, Sahagun-Flores JE, de Alba-Garcia JE, et al: Sensitization of cervix cancer cells to Adriamycin by Pentoxifylline induces an increase in apoptosis and decrease senescence. Mol Cancer 2010, 9:114.

9. Lerma-Diaz JM, Hernandez-Flores G, Dominguez-Rodriguez JR, OrtizLazareno PC, Gomez-Contreras P, Cervantes-Munguia R, Scott-Algara D, Aguilar-Lemarroy A, Jave-Suarez LF, Bravo-Cuellar A: In vivo and in vitro sensitization of leukemic cells to adriamycin-induced apoptosis by pentoxifylline. Involvement of caspase cascades and lkappaBalpha phosphorylation. Immunol Lett 2006, 103(2):149-158.

10. Adrain C, Martin SJ: Apoptosis: calling time on apoptosome activity. Sci Signal 2009, 2(91):pe62.
11. Pop C, Salvesen GS: Human caspases: activation, specificity, and regulation. J Biol Chem 2009, 284(33):21777-21781.

12. Smith MA, Schnellmann RG: Calpains, mitochondria, and apoptosis. Cardiovasc Res 2012, 96(1):32-37.

13. Sarmento-Ribeiro AB, Dourado M, Paiva A, Freitas A, Silva T, Regateiro F, Oliveira CR: Apoptosis deregulation influences chemoresistance to azaguanine in human leukemic cell lines. Cancer Invest 2012, 30(5):331-342.

14. Aoudjit F, Vuori K: Integrin signaling in cancer cell survival and chemoresistance. Chemotherapy research and practice 2012, 2012:283181.

15. Ahn KS, Sethi G, Aggarwal BB: Reversal of chemoresistance and enhancement of apoptosis by statins through down-regulation of the NF-kappaB pathway. Biochem Pharmacol 2008, 75(4):907-913.

16. Tracey L, Streck CJ, Du Z, Williams RF, Pfeffer LM, Nathwani AC, Davidoff AM NF-kappaB activation mediates resistance to IFN beta in MLL-rearranged acute lymphoblastic leukemia. Leukemia 2010, 24(4):806-812.

17. Choi YH, Park HY: Anti-inflammatory effects of spermidine in lipopolysaccharide-stimulated BV2 microglial cells. J Biomed Sci 2012, 19:31.

18. Chang CC, Lu WJ, Ong ET, Chiang CW, Lin SC, Huang SY, Sheu JR: A novel role of sesamol in inhibiting NF-kappaB-mediated signaling in platelet activation. J Biomed Sci 2011, 18:93.

19. Oiso S, Ikeda R, Nakamura K, Takeda Y, Akiyama S, Kariyazono H: Involvement of NF-kappaB activation in the cisplatin resistance of human epidermoid carcinoma KCP-4 cells. Oncol Rep 2012, 28(1):27-32.

20. Yadav VR, Prasad S, Gupta SC, Sung B, Phatak SS, Zhang S, Aggarwal BB: 3-Formylchromone interacts with cysteine 38 in p65 protein and with cysteine 179 in IkappaBalpha kinase, leading to down-regulation of nuclear factor-kappaB (NF-kappaB)-regulated gene products and sensitization of tumor cells. J Biol Chem 2012, 287(1):245-256.

21. Deorukhkar A, Krishnan S: Targeting inflammatory pathways for tumor radiosensitization. Biochem Pharmacol 2010, 80(12):1904-1914.

22. Fakler M, Loeder S, Vogler M, Schneider K, Jeremias I, Debatin KM, Fulda S: Small molecule XIAP inhibitors cooperate with TRAIL to induce apoptosis in childhood acute leukemia cells and overcome $\mathrm{Bcl}-2$ -mediated resistance. Blood 2009, 113(8):1710-1722.

23. Hernandez-Flores G, Ortiz-Lazareno PC, Lerma-Diaz JM, DominguezRodriguez JR, Jave-Suarez LF, Aguilar-Lemarroy Adel C, de Celis-Carrillo R, del Toro-Arreola S, Castellanos-Esparza YC, Bravo-Cuellar A: Pentoxifylline sensitizes human cervical tumor cells to cisplatin-induced apoptosis by suppressing NF-kappa B and decreased cell senescence. BMC Cancer 2011, 11:483.

24. Barancik M, Bohacova V, Gibalova L, Sedlak J, Sulova Z, Breier A: Potentiation of anticancer drugs: effects of pentoxifylline on neoplastic cells. Int J Mol Sci 2012, 13(1):369-382.

25. Goel PN, Gude RP: Unravelling the antimetastatic potential of pentoxifylline, a methylxanthine derivative in human MDA-MB-231 breast cancer cells. Mol Cell Biochem 2011, 358(1-2):141-151.

26. Green LA, Kim C, Gupta SK, Rajashekhar G, Rehman J, Clauss M: Pentoxifylline reduces tumor necrosis factor-alpha and HIV-induced vascular endothelial activation. AIDS Res Hum Retroviruses 2012, 28(10):1207-1215.

27. Ortiz-Lazareno PC, Hernandez-Flores G, Dominguez-Rodriguez JR, LermaDiaz JM, Jave-Suarez LF, Aguilar-Lemarroy A, Gomez-Contreras PC, ScottAlgara D, Bravo-Cuellar A: MG132 proteasome inhibitor modulates proinflammatory cytokines production and expression of their receptors in U937 cells: involvement of nuclear factor-kappaB and activator protein-1. Immunology 2008, 124(4):534-541.

28. Landis-Piwowar KR: Proteasome inhibitors in cancer therapy: a novel approach to a ubiquitous problem. Clin Lab Sci 2012, 25(1):38-44.

29. Kisselev AF, van der Linden WA, Overkleeft HS: Proteasome inhibitors: an expanding army attacking a unique target. Chem Biol 2012, 19(1):99-115.

30. Catalgol B: Proteasome and cancer. Prog Mol Biol Trans/ Sci 2012, 109:277-293.

31. Park HS, Jun do Y, Han CR, Woo HJ, Kim YH: Proteasome inhibitor MG132induced apoptosis via ER stress-mediated apoptotic pathway and its potentiation by protein tyrosine kinase p56lck in human Jurkat T cells. Biochem Pharmacol 2011, 82(9):1110-1125.

32. Neutzner A, Li S, Xu S, Karbowski M: The ubiquitin/proteasome systemdependent control of mitochondrial steps in apoptosis. Semin Cell Dev Biol 2012, 23(5):499-508

33. Gomez-Contreras PC, Hernandez-Flores G, Ortiz-Lazareno PC, Del ToroArreola S, Delgado-Rizo V, Lerma-Diaz JM, Barba-Barajas M, Dominguez- 
Rodriguez JR, Bravo Cuellar A: In vitro induction of apoptosis in U937 cells by perillyl alcohol with sensitization by pentoxifylline: increased BCL-2 and BAX protein expression. Chemotherapy 2006, 52(6):308-315.

34. Hernandez-Flores G, Bravo-Cuellar A, Aguilar-Luna JC, Lerma-Diaz JM, BarbaBarajas M, Orbach-Arbouys S: [In vitro induction of apoptosis in acute myelogenous and lymphoblastic leukemia cells by adriamycine is increased by pentoxifylline]. Presse Med 2010, 39(12):1330-1331.

35. Misra S, Sharma S, Agarwal A, Khedkar SV, Tripathi MK, Mittal MK, Chaudhuri $\mathrm{G}$ : Cell cycle-dependent regulation of the bi-directional overlapping promoter of human BRCA2/ZAR2 genes in breast cancer cells. Mol Cancer 2010, 9:50.

36. Niu XF, Liu BQ, Du ZX, Gao YY, Li C, Li N, Guan Y, Wang HQ: Resveratrol protects leukemic cells against cytotoxicity induced by proteasome inhibitors via induction of FOXO1 and p27Kip1. BMC Cancer 2011, 11:99.

37. Sung ES, Park KJ, Choi HJ, Kim CH, Kim YS: The proteasome inhibitor MG132 potentiates TRAIL receptor agonist-induced apoptosis by stabilizing tBid and Bik in human head and neck squamous cell carcinoma cells. Exp Cell Res 2012, 318(13):1564-1576.

38. You BR, Park WH: The enhancement of propyl gallate-induced apoptosis in HeLa cells by a proteasome inhibitor MG132. Oncol Rep 2011 25(3):871-877.

39. Pilat MJ, Kamradt JM, Pienta KJ: Hormone resistance in prostate cancer. Cancer Metastasis Rev 1998, 17(4):373-381.

40. Mantena SK, Sharma SD, Katiyar SK: Berberine, a natural product, induces G1-phase cell cycle arrest and caspase-3-dependent apoptosis in human prostate carcinoma cells. Mol Cancer Ther 2006, 5(2):296-308.

41. Wurstle ML, Laussmann MA, Rehm M: The central role of initiator caspase9 in apoptosis signal transduction and the regulation of its activation and activity on the apoptosome. Exp Cell Res 2012, 318(11):1213-1220.

42. Dai Y, Rahmani M, Grant S: Proteasome inhibitors potentiate leukemic cell apoptosis induced by the cyclin-dependent kinase inhibitor flavopiridol through a SAPK/JNK- and NF-kappaB-dependent process. Oncogene 2003, 22(46)::7108-7122.

43. Ji Q, Jia H, Dai H, Li W, Zhang L: Protective effects of pentoxifylline on the brain following remote burn injury. Burns 2010, 36(8):1300-1308.

44. Juvekar A, Ramaswami S, Manna S, Chang TP, Zubair A, Vancurova I: Electrophoretic mobility shift assay analysis of NFkappaB transcriptional regulation by nuclear IkappaBalpha. Methods Mol Biol 2012, 809:49-62.

45. Perkins ND: The diverse and complex roles of NF-kappaB subunits in cancer. Nat Rev Cancer 2012, 12(2):121-132.

46. Sohma I, Fujiwara Y, Sugita Y, Yoshioka A, Shirakawa M, Moon JH, Takiguchi S, Miyata H, Yamasaki M, Mori M, et al: Parthenolide, an NF-kappaB inhibitor, suppresses tumor growth and enhances response to chemotherapy in gastric cancer. CANCER GENOMICS PROTEOMICS 2011 , 8(1):39-47.

47. Wang YW, Wang SJ, Zhou YN, Pan SH, Sun B: Escin augments the efficacy of gemcitabine through down-regulation of nuclear factor-kappaB and nuclear factor-kappaB-regulated gene products in pancreatic cancer both in vitro and in vivo. J Cancer Res Clin Oncol 2012, 138(5):785-797.

48. Go HS, Seo JE, Kim KC, Han SM, Kim P, Kang YS, Han SH, Shin CY, Ko KH: Valproic acid inhibits neural progenitor cell death by activation of NFkappaB signaling pathway and up-regulation of BCl-XL. J Biomed Sci 2011, 18(1):48.

49. Cao W, Shiverick KT, Namiki K, Sakai Y, Porvasnik S, Urbanek C, Rosser CJ: Docetaxel and bortezomib downregulate $\mathrm{BCl}-2$ and sensitize $\mathrm{PC}-3-\mathrm{BCl}-2$ expressing prostate cancer cells to irradiation. World J Urol 2008, 26(5):509-516

50. Mena S, Rodriguez ML, Ortega A, Priego S, Obrador E, Asensi M, Petschen I, Cerda M, Brown BD, Estrela JM: Glutathione and Bcl-2 targeting facilitates elimination by chemoradiotherapy of human A375 melanoma xenografts overexpressing bcl-xl, bcl-2, and mcl-1. J Trans/ Med 2012, $10: 8$.

51. Chanvorachote $P$, Pongrakhananon $V$, Wannachaiyasit $S$, Luanpitpong $S$, Rojanasakul Y, Nimmannit U: Curcumin sensitizes lung cancer cells to cisplatin-induced apoptosis through superoxide anion-mediated Bcl-2 degradation. Cancer Invest 2009, 27(6):624-635.

52. Kannaiyan R, Hay HS, Rajendran P, Li F, Shanmugam MK, Vali S, Abbasi T, Kapoor S, Sharma A, Kumar AP, et al: Celastrol inhibits proliferation and induces chemosensitization through down-regulation of NF-kappaB and STAT3 regulated gene products in multiple myeloma cells. $\mathrm{Br} J$ Pharmacol 2011, 164(5):1506-1521.
53. Choi YH, Park HS: Apoptosis induction of U937 human leukemia cells by diallyl trisulfide induces through generation of reactive oxygen species. J Biomed Sci 2012, 19(1):50

54. Estaquier J, Vallette F, Vayssiere JL, Mignotte B: The mitochondrial pathways of apoptosis. Adv Exp Med Biol 2012, 942:157-183.

55. Gupta S, Kass GE, Szegezdi E, Joseph B: The mitochondrial death pathway: a promising therapeutic target in diseases. J Cell Mol Med 2009, 13(6):1004-1033.

56. Li Z, Huang Y, Dong F, Li W, Ding L, Yu G, Xu D, Yang Y, X X X, Tong D: Swainsonine promotes apoptosis in human oesophageal squamous cell carcinoma cells in vitro and in vivo through activation of mitochondrial pathway. J Biosci 2012, 37(6):1005-1016.

doi:10.1186/1423-0127-20-13

Cite this article as: Bravo-Cuellar et al:: Pentoxifylline and the proteasome inhibitor MG132 induce apoptosis in human leukemia U937 cells through a decrease in the expression of $\mathrm{BCl}-2$ and $\mathrm{BCl}-\mathrm{XL}$ and phosphorylation of p65. Journal of Biomedical Science 2013 20:13.

\section{Submit your next manuscript to BioMed Central and take full advantage of:}

- Convenient online submission

- Thorough peer review

- No space constraints or color figure charges

- Immediate publication on acceptance

- Inclusion in PubMed, CAS, Scopus and Google Scholar

- Research which is freely available for redistribution
Ciomed Central 